\title{
Corn Silage Management II: Effects of Hybrid, Maturity, and Mechanical Processing on Digestion and Energy Content
}

\author{
L. M. Johnson, ${ }^{*}$ J. H. Harrison, ${ }^{*}$ D. Davidson, ${ }^{*}$ \\ M. Swift, $†$ W. C. Mahanna, $\ddagger$ and K. Shinners§ \\ *Department of Animal Sciences, Washington \\ State University, Puyallup 98371 \\ †Agro Pacific Industries, Inc., Chiliwack, BC \\ fPioneer Hi-Bred International, Des Moines, IA 50131 \\ $\S$ Department of Biological System Engineering, \\ University of Wisconsin, Madison 53706
}

\section{ABSTRACT}

Two experiments were conducted to evaluate the effects of maturity and mechanical processing of two hybrids of whole plant corn on starch, fiber, and ether extract digestibilities and energy content of the total mixed ration fed to lactating Holstein cows. In the first experiment, Pioneer ${ }^{\circledR}$ hybrid 3845 whole plant corn was harvested at hard dough, one-third milkline, and twothirds milkline with a theoretical length of cut of 6.4 $\mathrm{mm}$. At each stage of maturity, corn was harvested with and without mechanical processing. In the second experiment, Pioneer ${ }^{\circledR}$ hybrids 3845 and Quanta were harvested at one-third milkline, two-thirds milkline, and blackline stages of maturity with and without mechanical processing. The theoretical length of cut was $12.7 \mathrm{~mm}$. The measured TDN and $\mathrm{NE}_{\mathrm{L}}$ concentrations were lower for diets containing processed corn silage in experiment 1 and greater for diets containing processed corn silage in experiment 2 , compared with diets containing unprocessed corn silage. The lower energy content for diets containing processed corn silage in experiment 1 can be explained by the lower total tract NDF, ether extract, and $\mathrm{CP}$ digestibilities. The greater energy content for diets containing processed corn silage in experiment 2 can be attributed to greater total tract starch and NDF digestibilities for cows fed processed corn silage diets. In experiment 2 , diets containing processed corn silage (1.59 Mcal $/ \mathrm{kg}$ ) had approximately $2.6 \%$ more energy available per kilogram of DM consumed compared with diets containing unprocessed corn silage (1.55 Mcal/kg). For hybrid Quanta in experiment 2, the TDN and $\mathrm{NE}_{\mathrm{L}}$ concentrations of diets containing corn silage harvested at two-thirds ML were greater than at other maturities.

Received January 2, 2001.

Accepted April 16, 2002.

Corresponding author: J. Harrison; e-mail: harrison@puyallup. wsu.edu.
(Key words: corn silage, mechanical processing, maturity, digestibility)

Abbreviation key: $\mathbf{B L}=$ blackline, $\mathbf{D E}=$ digestible energy, $\mathbf{M E}=$ metabolizable energy, $\mathbf{M L}=$ milkline, TLC = theoretical length of cut.

\section{INTRODUCTION}

During the mid- to late-1960's and mid-1980's, research was conducted to determine the stage of maturity that maximized nutritive value of corn silage (Huber et al., 1965; Huber et al., 1968; Buck et al., 1969; St. Pierre et al., 1987). When the DM concentration ranged between 33 and 36\%, crude fiber (Huber et al., 1965) and ADF (Huber et al., 1968; St. Pierre et al., 1987) concentrations were lower and intake of digestible nutrients was greater than corn silage harvested at other DM concentrations. These older studies are not typical of current management and feeding practices. Cows were fed diets high in forage (corn silage), the grain content of the forage was low, and milk yields were low compared with today's standards. Recently, two studies used current hybrids (greater grain content as a percentage of the whole plant) and feeding strategies to determine the stage of maturity that maximizes the nutritive value of corn silage of lactating dairy cows (Harrison et al., 1996; Bal et al., 1997). Total tract starch (Harrison et al., 1996; Bal et al., 1997) and ADF (Bal et al., 1997) digestibilities were greater $(P<0.05)$ for cows fed corn silage harvested at one-half milkline (ML) or two-thirds ML than blackline (BL). Estimated $\mathrm{NE}_{\mathrm{L}}$ concentration of the corn silage, using corn silage $\mathrm{DM}$ and ADF concentration from Bal et al. (1997) and Harrison et al. (1996) in the equations developed by Adams (1995), indicated that maximum nutritive value was obtained between one-half ML and two-thirds ML.

Since the mid-1990's, forage harvesters with onboard mechanical processors have gained widespread acceptance throughout the United States. Increasing the sur- 
face area exposed can potentially increase nutrient digestibility of the corn silage in the rumen and may lead to improvements in animal performance. Five studies have reported increased starch digestibility due to processing with an onboard mechanical processor attached to a forage harvester (Doggett, 1998; Harrison et al., 1998; Young et al., 1998; Bal et al., 2000a; Dhiman et al., 2000). Another study (Weiss and Wyatt, 2000) reported that total tract digestibilities of starch and nonfiber carbohydrates were significantly greater for lactating cows fed mechanically processed conventional corn silage harvested at one-half ML compared with unprocessed corn silage. Mechanically processed corn silage increased TDN of the conventional corn silage diet by $5.3 \%$ (Weiss and Wyatt, 2000).

The rapid adoption of onboard mechanical processing units has provided the need for research to determine the benefits of mechanically processing corn silage over a wide range of maturities. Two different hybrids of corn silage were chosen that differed in corn grain characteristics (Hybrid 3845, dent variety; Hybrid Quanta, flint variety) to determine if mechanical processing affected one type of hybrid to a greater extent. The objective of these experiments was to evaluate the effects of maturity and mechanical processing of two corn silage hybrids on the energy content of the diets and ruminal and total tract digestion of starch, fiber, and fat. The energy requirements for maintenance and milk production were evaluated also.

\section{MATERIALS AND METHODS}

\section{Cows, Diets, and Experimental Design}

Two total-collection digestion and metabolism studies were conducted using ruminally and duodenally cannulated lactating Holstein cows. Six ruminally and duodenally cannulated lactating Holstein cows were used in a $6 \times 6$ Latin square design for experiment 1 . The experimental design structure in experiment 2 was similar to experiment 1 . However, each hybrid (Pioneer hybrids 3845 and Quanta) had a $6 \times 6$ Latin square structure. Six ruminally and duodenally cannulated lactating Holstein cows were used in each Latin square in experiment 2 , and the squares were conducted in tandem. In the experiments, corn silage was harvested with a self-propelled John Deere 5830 harvester (with a kernel processing unit) at a ground speed between 2 and $2.5 \mathrm{mph}$. The processing equipment was fully active. The harvester consisted of four knives per row, and there were 10 tangential rows. At each stage of maturity, corn silage was harvested with the kernel processing rolls set 1-mm clearance (processed) and with the kernel processing rolls set $15.9-\mathrm{mm}$ clearance (unprocessed). All corn silage was inoculated at the
Table 1. Ingredients of the diets fed in experiments 1 and 2 (DM basis).

\begin{tabular}{|c|c|c|}
\hline \multirow[b]{2}{*}{ Ingredient } & \multicolumn{2}{|c|}{ Experiment } \\
\hline & 1 & 2 \\
\hline & $\longrightarrow$ & 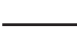 \\
\hline Corn silage & 26.8 & 26.8 \\
\hline Whole cottonseed & 13.6 & 13.6 \\
\hline Alfalfa hay & 13.2 & 13.2 \\
\hline Barley grain, steam rolled & 12.3 & 14.0 \\
\hline Corn grain, steam rolled & 9.3 & 14.0 \\
\hline Soybean meal, $47 \% \mathrm{CP}$, expeller processed & 8.3 & 5.1 \\
\hline Wheat, millrun & 6.5 & 4.2 \\
\hline Prolak $^{1}$ & 3.2 & 2.3 \\
\hline Beet pulp & 2.4 & 2.4 \\
\hline Sodium bicarbonate & 1.9 & 1.85 \\
\hline Molasses & 1.0 & 0.84 \\
\hline Limestone & 1.0 & 0.75 \\
\hline TM salt ${ }^{2}$ & 0.26 & \\
\hline Salt & $\ldots$ & 0.35 \\
\hline Biofos $^{3}$ & $\ldots$ & 0.30 \\
\hline $\mathrm{Mg}$ oxide & $\ldots$ & 0.19 \\
\hline WSU mineral premix ${ }^{4}$ & $\ldots$ & 0.12 \\
\hline $\mathrm{Se}^{5}$ & 0.12 & $\ldots$ \\
\hline TM mineral ${ }^{6}$ & 0.07 & $\ldots$ \\
\hline Vitamin $\mathrm{D}^{7}$ & 0.02 & $\ldots$ \\
\hline Vitamin $\mathrm{A}^{8}$ & 0.02 & $\ldots$ \\
\hline Vitamin $\mathrm{E}^{9}$ & 0.01 & $\ldots$ \\
\hline
\end{tabular}

${ }^{1}$ Prolak-H.J. Baker \& Bro., Inc., (Stamford, CT).

${ }^{2} \mathrm{TM}$ Salt_-59\% Cl; $38 \% \mathrm{Na} ; 4$ ppm Cu; 18 ppm Fe; 0.7 ppm I; 28 ppm Mn; 35 ppm Zn.

${ }^{3}$ Biofos-IMC (Lake Forest, IL).

${ }^{4}$ WSU Mineral Premix - $5863 \mathrm{kIU} / \mathrm{kg}$ of Vitamin A; $2640 \mathrm{kIU} / \mathrm{kg}$ or Vitamin D; 14,674 IU/kg of Vitamin E; $220 \mathrm{ppm} \mathrm{Co;} 16,500 \mathrm{ppm}$ $\mathrm{Cu} ; 660$ ppm Fe; 880 ppm I; 44,000 ppm Mn; 220 ppm Se; 44,000 ppm Zn.

${ }^{5} \mathrm{Se}-198 \mathrm{ppm}$

${ }^{6} \mathrm{TM}$ Mineral-20\% Mg; 13,000 ppm Cu; 66,000 ppm Fe; 2,900 ppm I; 44,000 ppm Mn; 120,000 ppm Zn.

${ }^{7}$ Vitamin D—24,000 kIU/kg.

${ }^{8}$ Vitamin A-29,964 kIU/kg.

${ }^{9}$ Vitamin E—498,960 IU/kg.

harvester with Pioneer 1132 (Pioneer Hi-Bred Int., Inc., Johnston, IA) inoculant.

All cows used in these experiments were multiparous. Experimental periods were $14 \mathrm{~d}$; the first $10 \mathrm{~d}$ were for adjustment, and the last $4 \mathrm{~d}$ were for collection of samples and data. Cows were individually fed with Calan headgates (American Calan, Inc., Northwood, $\mathrm{NH}$ ) in a free-stall barn during the adaptation periods. Cows were fed enough TMR twice daily (1000 and 1600 h) to allow $10 \%$ orts. In all experiments, cows were fed diets balanced to meet NRC specifications (National Research Council, 1989) and containing a similar proportion of corn silage ( $26.8 \%$ of diet DM), alfalfa hay (13.2\% of diet DM), whole cottonseed (13.6\% of diet $\mathrm{DM}$ ), and grain mix (46.4\% of diet DM; Table 1).

The effects of maturity (three stages) and mechanical processing (with and without) of two corn silage hybrids 
(Pioneer hybrids 3845 and Quanta) on fiber, starch, and ether extract digestion and energy availability of the TMR were evaluated in experiments 1 and 2 .

Experiment 1. Cows averaged 126 DIM at the beginning of the experiment. Pioneer hybrid 3845 corn silage was harvested during the 1996 growing season. Corn silage was harvested at hard dough (25.3 DM\%), onethird ML (28.5 DM\%), and two-thirds ML (27.9 DM\% with two light frosts and one killing frost) stages of maturity. The theoretical length of cut (TLC) for the corn silage was $6.4 \mathrm{~mm}$. Corn silage was stored in $\mathrm{Ag}$ Bags (Ag Bag International, Ltd., Warrenton, OR).

Experiment 2. Pioneer hybrid 3845 corn silage was harvested during the 1997 growing season at one-third ML (27.1 DM\%), two-thirds ML (33.3 DM\%), and BL (38.2 DM\%) stages of maturity. The TLC for the corn silage was $12.7 \mathrm{~mm}$. Corn silage was stored in bunker silos. Cows fed hybrid 3845 corn silage averaged 140 DIM at the beginning of the experiment. Hybrid Quanta corn silage was harvested during the 1997 growing season at one-third ML (34.1 DM\%), two-thirds ML (41.5 $\mathrm{DM} \%$ ), and $\mathrm{BL}$ (47.5 DM\%) stages of maturity. The TLC for the corn silage was $12.7 \mathrm{~mm}$. Cows fed hybrid Quanta corn silage averaged 128 DIM at the beginning of the experiment.

\section{Sample Collection}

Cows were housed in a metabolism barn during the collection period (d 11 through 14). Bodyweights were recorded at the beginning (prior to entering the metabolism barn) and end (prior to entering the free-stall barn) of the collection period. Milk yield was measured twice daily at 0700 and $1900 \mathrm{~h}$. Total mixed rations were provided individually to cows twice daily at 1000 and $1600 \mathrm{~h}$. Weights were recorded, and samples were collected once daily for the corn silage, TMR, and orts. Samples were frozen until further analysis $\left(-20^{\circ} \mathrm{C}\right)$. Urine was collected via urine cups (Fellner et al., 1988) and flowed through polyvinyl tubing into a collection jug located beneath the floor. Hydrochloric acid (36.5\%) was added to the urine to maintain the $\mathrm{pH}<4$ to minimize loss of ammonia. Urine was weighed once daily, and $1 \%$ of the total weight was subsampled and frozen for further analysis $\left(-20^{\circ} \mathrm{C}\right)$. Feces passed through grates in the floor and were collected in tubs located beneath the floor. Feces were weighed once daily, and $1 \%$ of the total weight was subsampled and frozen for further analysis $\left(-20^{\circ} \mathrm{C}\right)$. Corn silage, TMR, orts, urine, and fecal samples were composited across the $4 \mathrm{~d}$ of collection for each period by cow.

Grass silage labeled with $\mathrm{Yb}$ was prepared prior to the beginning of each experiment and used as a particulate flow marker. Silage was prepared by spraying $\mathrm{Yb}$ -
$\mathrm{Cl}_{3} \cdot 6 \mathrm{H}_{2} \mathrm{O}$ dissolved in water to reach a final concentration of $2.5 \% \mathrm{Yb}$ in silage DM (Hartnell and Satter, 1979). Once silage was sprayed with $\mathrm{YbCl}_{3} \cdot 6 \mathrm{H}_{2} \mathrm{O}$, the silage was dried at $55^{\circ} \mathrm{C}$ in a forced-air oven for $48 \mathrm{~h}$. On d 7 through 9 of each period, 20-g aliquots of silage labeled with $\mathrm{Yb}$ were added via the ruminal cannula once daily. On d 10 through 13, silage labeled with $\mathrm{Yb}$ was dosed twice daily (12 h apart) in 10-g aliquots. Duodenal and ileal samples were taken four times daily at 6-h intervals from d 11 to 13 . On d 12 and 13, sampling time was moved forward $2 \mathrm{~h} / \mathrm{d}$ to allow for samples to be obtained every even $h$ of a $24-h d$. The initial sample was taken at $0600 \mathrm{~h}$ on $\mathrm{d} 11$. During the collection of duodenal samples, the initial flow of duodenal contents (approximately $200 \mathrm{ml}$ ) from the cannula was discarded, and the next $200 \mathrm{ml}$ were collected and frozen at $-20^{\circ} \mathrm{C}$.

\section{Sample Preparation and Analysis}

At the end of each collection period, samples of corn silage, TMR, orts, and feces were dried at $55^{\circ} \mathrm{C}$ in a forced-air oven. Duodenal samples were thawed and blended at high speed for 3 min with a Waring blender and dried at $55^{\circ} \mathrm{C}$ in a forced-air oven. Dried corn silage, TMR (Tables 2 and 3), orts, duodenal, and fecal samples were ground through a 1-mm screen using a Wiley mill (Arthur H. Thomas, Philadelphia, PA) and analyzed for DM and ash (AOAC, 1990). Corn silage, TMR (Tables 2 and 3), orts, duodenal contents, and feces were analyzed for NDF with sulfite (Van Soest et al., 1991), ADF (Goering and Van Soest, 1970), and starch (modified version of Holm et al., 1986; described in Johnson et al., 2002). Total mixed rations (Tables 2 and 3), orts, and feces were analyzed for ether extract (AOAC, 1990). Total mixed rations were analyzed for CP (AOAC, 1990), lignin (Goering and Van Soest, 1970), acid detergent insoluble CP (Goering and Van Soest, 1970), and neutral detergent insoluble CP (Goering and Van Soest, 1970; Tables 2 and 3). Hemicellulose concentration of the TMR and orts was calculated by subtracting ADF concentration from NDF concentration (not corrected for neutral detergent insoluble $\mathrm{CP}$ ), and cellulose concentration of the TMR and orts was calculated by subtracting lignin concentration from $\mathrm{ADF}$ concentration. Nonfiber carbohydrate concentration for the TMR was calculated using the formula: nonfiber carbohydrate $=$ $100-(\mathrm{NDF}+\mathrm{CP}+$ ether extract + ash $)$. The NDF concentration in the nonfiber carbohydrate calculation was not corrected for neutral detergent insoluble CP.

Dried duodenal samples were analyzed for $\mathrm{Yb}$ concentration by the inductively coupled plasma (ICP) procedure (Fassel, 1978) using an extraction procedure described by Williams et al. (1962). Energy content of 
Table 2. Dry matter and chemical composition of the diets offered in experiment 1 (hybrid 3845 harvested in 1996).

\begin{tabular}{|c|c|c|c|c|c|c|}
\hline \multirow[b]{2}{*}{ Item } & \multicolumn{2}{|c|}{ Hard dough } & \multicolumn{2}{|c|}{ One-third milkline } & \multicolumn{2}{|c|}{ Two-thirds milkline } \\
\hline & Proc. ${ }^{1}$ & Unproc. ${ }^{2}$ & Proc. & Unproc. & Proc. & Unproc. \\
\hline DM, \% & 52.6 & 54.6 & 55.9 & 56.4 & 54.9 & 55.7 \\
\hline Ash, $\%$ of DM & 9.0 & 8.5 & 8.2 & 8.3 & 8.4 & 8.6 \\
\hline NDF, $\%$ of DM & 41.4 & 40.3 & 40.6 & 40.4 & 41.3 & 42.0 \\
\hline $\mathrm{ADF}, \%$ of $\mathrm{DM}$ & 26.5 & 25.3 & 25.5 & 24.8 & 25.6 & 26.1 \\
\hline $\mathrm{CP}, \%$ of $\mathrm{DM}$ & 18.1 & 17.9 & 17.7 & 18.1 & 18.3 & 18.5 \\
\hline $\mathrm{NFC}, \%$ of $\mathrm{DM}^{3}$ & 27.0 & 28.3 & 28.8 & 28.8 & 27.3 & 25.6 \\
\hline Starch, \% of DM & 19.2 & 18.9 & 19.7 & 18.3 & 19.7 & 20.2 \\
\hline Lignin, \% of DM & 5.7 & 5.1 & 5.4 & 5.2 & 4.9 & 4.5 \\
\hline $\mathrm{ADICP}, \%$ of $\mathrm{DM}^{4}$ & 1.7 & 1.2 & 1.3 & 1.6 & 1.4 & 1.4 \\
\hline NDICP, $\%$ of $\mathrm{DM}^{5}$ & 5.1 & 5.1 & 4.6 & 4.8 & 2.0 & 2.1 \\
\hline Crude fat, $\%$ of DM & 4.5 & 5.0 & 4.6 & 4.5 & 4.7 & 5.3 \\
\hline
\end{tabular}

${ }^{1}$ Proc.-Corn silage was harvested with kernel processing rolls set $1 \mathrm{~mm}$ apart.

${ }^{2}$ Unproc.-Corn silage was harvested with kernel processing rolls set $15.9 \mathrm{~mm}$ apart.

${ }^{3} \mathrm{NFC}-$ Nonfiber carbohydrates $=100-(\mathrm{CP}+\mathrm{NDF}+$ ash + ether extract $)$.

${ }^{4} \mathrm{ADICP}-$ Acid detergent insoluble CP.

${ }^{5} \mathrm{NDICP}-\mathrm{Neutral}$ detergent insoluble CP.

dried and ground samples of TMR, orts, and feces was determined by combustion in an adiabatic oxygen bomb calorimeter (Adiabatic Calorimeter, Parr. Moline, IL). Urine was analyzed for CP (AOAC, 1990), and urinary energy (Kcal $/ \mathrm{kg}$ ) was estimated using the formula: [23.8 + (125.0 $\times$ nitrogen $)$; Elliot and Loosli, 1959]. Methane energy (Mcal/d) was estimated using the formula: $[0.814+0.122 \times$ nonfiber carbohydrates (kg consumed/ d) $+0.415 \times$ hemicellulose $(\mathrm{kg}$ consumed $/ \mathrm{d})+0.633 \times$ cellulose (kg consumed/d); Moe and Tyrell, 1979]. Measured TDN was calculated using the following equation: Measured TDN = digestible CP + digestible nonfiber carbohydrates + digestible NDF + (digestible ether ex- tract $\times 2.25)$. Net energy of lactation $\left(\mathrm{NE}_{\mathrm{L}}\right)$ was estimated from measured TDN with: $\mathrm{NE}_{\mathrm{L}}(\mathrm{Mcal} / \mathrm{kg}$ of $\mathrm{DM})$ $=[0.0245 \times \mathrm{TDN}(\%$ of DM) $]-0.12(\mathrm{NRC}, 1989)$. Calculated TDN was estimated using the following equation: Calculated TDN = digestible energy [DE; Mcal $/ \mathrm{kg}] /$ 0.04409 (NRC, 1989).

\section{Statistical Analysis}

The model to test for treatment differences in experiment 1 and Experiment 2 was:

$$
\mathrm{Y}_{\mathrm{ijk}}=\mu+\mathrm{C}_{\mathrm{i}}+\mathrm{P}_{\mathrm{j}}+\mathrm{T}_{\mathrm{k}}+\mathrm{E}_{\mathrm{ijk}}
$$

Table 3. Dry matter and chemical composition of the diets offered in experiment 2 (hybrids 3845 and Quanta harvested in 1997).

\begin{tabular}{|c|c|c|c|c|c|c|c|c|c|c|c|c|}
\hline \multirow[b]{3}{*}{ Item } & \multicolumn{6}{|c|}{ Experiment 2 (hybrid 3845 ) } & \multicolumn{6}{|c|}{ Experiment 2 (hybrid Quanta) } \\
\hline & \multicolumn{2}{|c|}{$\begin{array}{l}\text { One-third } \\
\text { milkline }\end{array}$} & \multicolumn{2}{|c|}{$\begin{array}{l}\text { Two-thirds } \\
\text { milkline }\end{array}$} & \multicolumn{2}{|c|}{ Blackline } & \multicolumn{2}{|c|}{$\begin{array}{l}\text { One-third } \\
\text { milkine }\end{array}$} & \multicolumn{2}{|c|}{$\begin{array}{l}\text { Two-thirds } \\
\text { milkline }\end{array}$} & \multicolumn{2}{|c|}{ Blackline } \\
\hline & Proc. $^{1}$ & Unproc. $^{2}$ & Proc. & Unproc. & Proc. & Unproc. & Proc. & Unproc. & Proc. & Unproc. & Proc. & Unproc. \\
\hline DM, \% & 55.6 & 58.1 & 61.9 & 61.2 & 64.5 & 66.5 & 59.2 & 63.2 & 66.7 & 67.5 & 68.3 & 74.2 \\
\hline Ash, \% of DM & 5.97 & 5.68 & 5.55 & 5.50 & 5.86 & 5.76 & 7.75 & 7.53 & 7.11 & 7.29 & 7.87 & 7.28 \\
\hline NDF, \% of DM & 33.6 & 33.8 & 35.1 & 33.7 & 34.9 & 34.7 & 32.1 & 31.5 & 31.8 & 32.5 & 33.6 & 32.3 \\
\hline $\mathrm{ADF}, \%$ of $\mathrm{DM}$ & 24.1 & 23.9 & 23.9 & 22.9 & 24.1 & 25.0 & 21.5 & 20.6 & 20.9 & 22.0 & 22.1 & 22.3 \\
\hline $\mathrm{CP}, \%$ of $\mathrm{DM}$ & 15.3 & 15.3 & 15.0 & 14.7 & 14.8 & 14.8 & 16.5 & 16.5 & 16.0 & 16.1 & 15.9 & 16.3 \\
\hline $\mathrm{NFC}, \%$ of $\mathrm{DM}^{3}$ & 39.0 & 39.9 & 39.5 & 40.8 & 38.9 & 39.5 & 38.7 & 38.8 & 38.7 & 38.4 & 39.2 & 36.5 \\
\hline Starch, \% of DM & 24.9 & 26.0 & 27.8 & 26.4 & 27.2 & 27.0 & 27.5 & 29.0 & 28.9 & 27.4 & 27.6 & 30.7 \\
\hline Lignin, $\%$ of DM & 4.8 & 4.8 & 4.3 & 4.0 & 5.4 & 5.4 & 4.1 & 3.3 & 3.6 & 4.4 & 2.7 & 4.6 \\
\hline $\mathrm{ADICP}, \%$ of $\mathrm{DM}^{4}$ & 1.0 & 1.1 & 0.9 & 0.9 & 1.1 & 1.0 & 2.5 & 1.7 & 1.1 & 1.1 & 1.3 & 1.1 \\
\hline NDICP, $\%$ of $\mathrm{DM}^{5}$ & 1.6 & 1.4 & 1.5 & 1.2 & 1.3 & 1.5 & 2.3 & 1.8 & 2.0 & 1.8 & 1.8 & 2.0 \\
\hline Crude fat, $\%$ of DM & 6.1 & 5.4 & 5.5 & 5.3 & 5.5 & 5.2 & 4.8 & 4.7 & 5.4 & 5.3 & 4.6 & 4.5 \\
\hline
\end{tabular}

${ }^{1}$ Proc.-Corn silage was harvested with kernel processing rolls set $1 \mathrm{~mm}$ apart.

${ }^{2}$ Unproc.-Corn silage was harvested with kernel processing rolls set $15.9 \mathrm{~mm}$ apart.

${ }^{3} \mathrm{NFC}-$ Nonfiber carbohydrates $=100-(\mathrm{CP}+\mathrm{NDF}+$ ash + ether extract $)$.

${ }^{4} \mathrm{ADICP}$-Acid detergent insoluble CP.

${ }^{5} \mathrm{NDICP}-$ Neutral detergent insoluble CP. 
where $\mu$ = overall mean, $\mathrm{C}_{\mathrm{i}}=$ cow effect ( $\mathrm{i}=1$ to 6$), \mathrm{P}_{\mathrm{j}}=$ period effect $(\mathrm{j}=1$ to 6$), \mathrm{T}_{\mathrm{k}}=$ treatment effect $(\mathrm{k}=1$ to 6 ), and $\mathrm{E}_{\mathrm{ijk}}=$ error term.

The model to test for main effects and interactions in experiment 1 was:

$$
\mathrm{Y}_{\mathrm{ijkl}}=\mu+\mathrm{C}_{\mathrm{i}}+\mathrm{P}_{\mathrm{j}}+\mathrm{M}_{\mathrm{k}}+\mathrm{K}_{\mathrm{l}}+(\mathrm{M} \times \mathrm{K})_{\mathrm{kl}}+\mathrm{E}_{\mathrm{ijkl}},
$$

where $\mu$ overall mean, $\mathrm{C}_{\mathrm{i}}=$ cow effect ( $\mathrm{i}=1$ to 6 ), $\mathrm{P}_{\mathrm{j}}$ $=$ period effect $(\mathrm{j}=1$ to 6$), \mathrm{M}_{\mathrm{k}}=$ maturity effect $(\mathrm{k}=1$ to 3$), \mathrm{K}_{\mathrm{l}}=$ processing effect $(\mathrm{l}=1$ to 2$),(\mathrm{M} \times \mathrm{K})_{\mathrm{kl}}=$ interaction effect of $\mathrm{M}_{\mathrm{k}}$ and $\mathrm{K}_{\mathrm{l}}$, and $\mathrm{E}_{\mathrm{ijkl}}=$ error term.

The model to test for main effects and interactions in experiment 2 was:

$$
\begin{gathered}
\mathrm{Y}_{\mathrm{ijklm}}=\mu+\mathrm{C}_{\mathrm{i}}(\mathrm{H})_{\mathrm{k}}+\mathrm{P}_{\mathrm{j}}+\mathrm{H}_{\mathrm{k}}+\mathrm{M}_{\mathrm{l}}+\mathrm{K}_{\mathrm{m}}+(\mathrm{H} \times \mathrm{M})_{\mathrm{kl}} \\
+(\mathrm{H} \times \mathrm{K})_{\mathrm{km}}+(\mathrm{M} \times \mathrm{K})_{\mathrm{lm}}+(\mathrm{H} \times \mathrm{P})_{\mathrm{kj}}+\mathrm{E}_{\mathrm{ijklm}},
\end{gathered}
$$

where $\mu$ overall mean, $\mathrm{C}_{\mathrm{i}}(\mathrm{H})_{\mathrm{k}}=$ cow effect nested within hybrid ( $\mathrm{i}=1$ to 12 ), $\mathrm{P}_{\mathrm{j}}=$ period effect $(\mathrm{j}=1$ to 6), $\mathrm{H}_{\mathrm{k}}=$ hybrid effect ( $\mathrm{k}=1$ to 2$), \mathrm{M}_{\mathrm{l}}=$ maturity effect $(1=1$ to 3$), K_{m}=$ processing effect $(\mathrm{m}=1$ to 2$),(\mathrm{H}$ $\times M)_{\mathrm{kl}}=$ interaction effect of $\mathrm{H}_{\mathrm{k}}$ and $\mathrm{M}_{\mathrm{l}},(\mathrm{H} \times \mathrm{K})_{\mathrm{km}}=$ interaction effect of $\mathrm{H}_{\mathrm{k}}$ and $\mathrm{K}_{\mathrm{m}},(\mathrm{M} \times \mathrm{K})_{\mathrm{lm}}=$ interaction effect of $\mathrm{M}_{\mathrm{l}}$ and $\mathrm{K}_{\mathrm{m}},(\mathrm{H} \times \mathrm{P})_{\mathrm{kj}}=$ interaction effect of $\mathrm{H}_{\mathrm{k}}$ and $P_{\mathrm{j}}$, and $\mathrm{E}_{\mathrm{ijk} k \mathrm{~m}}=$ error term. Significance was declared at $P<0.05$, and trends were observed at $P<0.10$ (SAS, 1988).

\section{RESULTS AND DISCUSSION}

\section{Intake and Digestion}

Starch intake and digestion. Starch intake was not affected by maturity or processing in experiment 1 (Table 4). Starch intake was greater $(P<0.002)$ for cows fed diets containing hybrid Quanta compared with hybrid 3845 (experiment 2; Table 4). The $6.4 \%$ increase in starch intake for cows fed diets containing hybrid Quanta corn silage was due to the $7.4 \%$ increase in starch concentration in the TMR containing hybrid Quanta corn silage (Table 3) because DMI was similar between hybrids (Table 5).

Starch intake increased $(P<0.0003)$ as maturity advanced from one-third ML to BL [experiment 2; Table 4]. The increase in starch intake was partially related to the 33 to $43 \%$ increase in starch concentration of corn silage harvested at two-thirds ML and BL compared with one-third ML for hybrid 3845 (experiment 2 ), and the 15 to $26 \%$ increase in starch concentration of corn silage as maturity advanced for hybrid Quanta (experiment 2; Johnson et al., 2002) because DMI was similar between hybrids (Table 5).

There was a hybrid by processing interaction and a maturity by processing interaction for starch intake in experiment 2 (Table 4). Starch intake tended to be greater $(P<0.06)$ for cows fed hybrid Quanta unprocessed corn silage based diets compared with the other treatments, and cows fed processed corn silage harvested at one-third ML maturity had significantly lower $(P<0.009)$ starch intake than the other treatments (Table 4). The greater intake of starch for cows fed diets containing hybrid Quanta unprocessed corn silage was due to the greater concentration of starch in the TMR (29\% starch) compared with other treatments $(27 \%$ starch; Table 3). The lower intake of starch for cows fed processed corn silage harvested at one-third ML maturity was due to a lower concentration of starch in the TMR $(\sim 26 \%$ starch $)$ compared with other treatments ( $28 \%$ starch; Table 3$)$.

Starch flow to the duodenum was not affected by treatment in experiment 1 and was influenced by maturity of corn silage and processing method in experiment 2 (Table 4). As maturity advanced from one-third ML to two-thirds ML, for hybrid 3845 in experiment 2, starch flow significantly increased $(P<0.05$; Table 4$)$. Starch flow to the duodenum was significantly lower for cows fed diets containing processed corn silage $(P$ $<0.0004$; Table 4). The greatest decrease $(P<0.01)$ in starch flow to the duodenum between processed and unprocessed corn silage treatments was achieved when corn silage was processed at two-thirds ML compared to processing corn silage at the other maturities (experiment 2; Table 4).

Two hybrids of corn silage differing in corn grain characteristics (hybrid 3845, dent characteristics; hybrid Quanta, flint characteristics) were selected in experiment 2 to evaluate the effects of maturity and mechanical processing on ruminal digestibility. In experiment 2, ruminal starch digestibility tended to be greater for the hybrid that was supposed to have a larger percentage of vitreous endosperm (70.2\%; hybrid Quanta) than the hybrid that was supposed to have a larger percentage of floury endosperm (67.1\%; hybrid $3845 ; P<0.07 ;$ Table 4 ). This differed from data reported in the literature which suggest that flint corn grains typically have a greater percentage of the endosperm that contains vitreous starch, whereas dent corn grains typically has a greater percentage of the endosperm that contains floury starch. The hybrids that contain a greater percentage of floury endosperm tend to have greater ruminal starch digestibility (Philippeau and Michalet-Doreau, 1997).

The difference in trends in ruminal starch digestibility between data reported in this paper and in the literature may be partially explained by the proportion of vitreous endosperm present in each hybrid as maturity of corn silage advanced. The proportion of vitreous starch present in the corn kernels for hybrid Quanta 
Table 4. Intake and digestion of starch (DM basis) in experiments 1 and 2 .

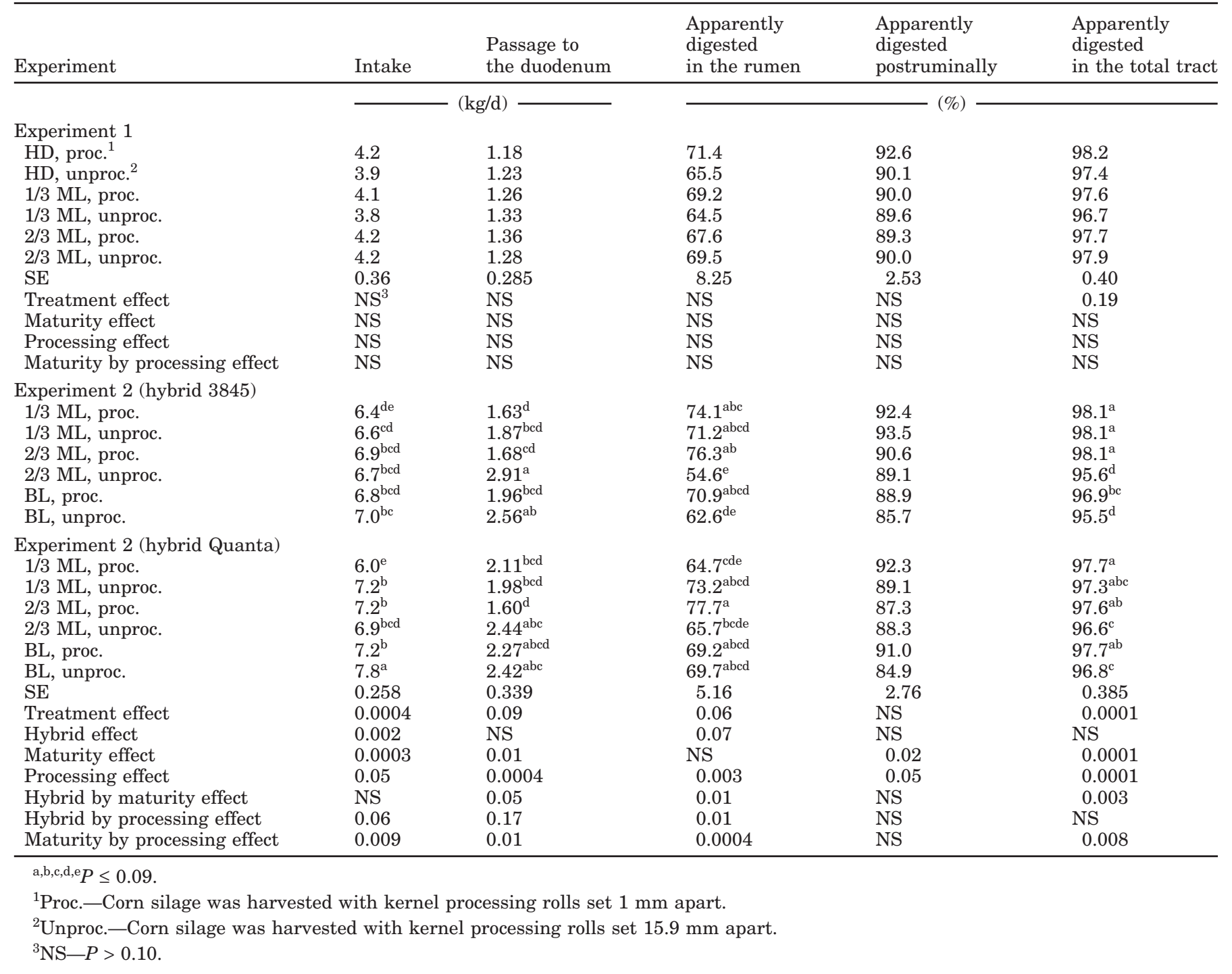

did not change drastically as maturity advanced (range of approximately 36 to $45 \%$; Johnson et al., 2002), and ruminal starch digestibility also did not change much as maturity advanced (range of approximately 69 to $72 \%$; Table 4). However, the proportion of vitreous starch present in the corn kernels for hybrid 3845 increased as the maturity of corn silage advanced from one-third ML (28.2\%) to BL (73.3\%; Johnson et al., 2002), and ruminal starch digestibility declined $(P<$ 0.01 ) as maturity of corn silage advanced from onethird ML to two-thirds ML and BL (Table 4). Therefore, the hybrid that was chosen for its dent characteristic (hybrid 3845) of increased proportion of floury endosperm (highly digestible) actually had a greater proportion of vitreous endosperm (less digestible) at the advanced maturities (two-thirds ML and BL) than hybrid Quanta (Johnson et al., 2002). This may partially ex- plain the reduction in ruminal starch digestibility for cows fed diets containing hybrid 3845 corn silage (dent characteristics) instead of diets containing hybrid Quanta corn silage (flint characteristics) (Table 4).

Mechanically processing corn silage had an effect on apparent digestion of starch in the rumen and lower tract (Table 4; experiment 2). Starch apparently digested in the rumen (experiment 2; $P<0.003$ ) and lower tract (experiment $2 ; P<0.05$ ) was significantly greater for cows fed processed corn silage (Table 4 ). There was a hybrid by processing interaction, and starch apparently digested in the rumen was greater $(P<0.01)$ for cows fed hybrid 3845 processed corn silage compared with hybrid 3845 unprocessed corn silage (Table 4). There was also a maturity by processing interaction, and starch apparently digested in the rumen was greater $(P<0.0004)$ for cows fed diets containing processed corn 
Table 5. Dry matter intake, body weight, and milk production in experiments 1 and 2.

\begin{tabular}{|c|c|c|c|}
\hline Experiment & Intake & $\begin{array}{l}\text { Body } \\
\text { weight }\end{array}$ & $\begin{array}{l}\text { Milk } \\
\text { production }\end{array}$ \\
\hline & $(\mathrm{kg} / \mathrm{d})$ & $(\mathrm{kg})$ & $(\mathrm{kg} / \mathrm{d})$ \\
\hline \multicolumn{4}{|l|}{ Experiment 1} \\
\hline HD, proc. ${ }^{1}$ & 21.8 & 650 & 26.0 \\
\hline HD, unproc. ${ }^{2}$ & 21.8 & 652 & 25.3 \\
\hline 1/3 ML, proc. & 20.9 & 647 & 23.8 \\
\hline 1/3 ML, unproc. & 21.2 & 657 & 28.9 \\
\hline 2/3 ML, proc. & 21.0 & 654 & 27.3 \\
\hline 2/3 ML, unproc. & 20.8 & 649 & 27.5 \\
\hline $\mathrm{SE}$ & 1.63 & 23.4 & 4.05 \\
\hline Treatment effect & $\mathrm{NS}^{3}$ & NS & NS \\
\hline Maturity effect & NS & NS & NS \\
\hline Processing effect & NS & NS & NS \\
\hline Maturity by processing effect & NS & NS & NS \\
\hline \multicolumn{4}{|l|}{ Experiment 2 (hybrid 3845) } \\
\hline 1/3 ML, proc. & 24.9 & $638^{\mathrm{cd}}$ & $37.6^{\mathrm{a}}$ \\
\hline 1/3 ML, unproc. & 24.3 & $635^{\mathrm{d}}$ & $38.1^{\mathrm{a}}$ \\
\hline 2/3 ML, proc. & 23.8 & $644^{\mathrm{bcd}}$ & $37.8^{\mathrm{a}}$ \\
\hline 2/3 ML, unproc. & 24.4 & $643^{\text {bcd }}$ & $38.0^{\mathrm{a}}$ \\
\hline BL, proc. & 24.0 & $634^{\mathrm{d}}$ & $37.9^{\mathrm{a}}$ \\
\hline $\mathrm{BL}$, unproc. & 24.1 & $640^{\text {cd }}$ & $37.7^{\mathrm{a}}$ \\
\hline \multicolumn{4}{|l|}{ Experiment 2 (hybrid Quanta) } \\
\hline 1/3 ML, proc. & 21.8 & $650^{\mathrm{abc}}$ & $31.9^{\mathrm{c}}$ \\
\hline 1/3 ML, unproc. & 23.6 & $655^{\mathrm{ab}}$ & $32.8^{\mathrm{bc}}$ \\
\hline 2/3 ML, proc. & 24.1 & $662^{\mathrm{a}}$ & $34.9^{\mathrm{b}}$ \\
\hline 2/3 ML, unproc. & 24.3 & $654^{\mathrm{ab}}$ & $32.5^{\mathrm{bc}}$ \\
\hline BL, proc. & 24.2 & $650^{\mathrm{abc}}$ & $32.8^{\mathrm{bc}}$ \\
\hline $\mathrm{BL}$, unproc. & 23.4 & $655^{\mathrm{ab}}$ & $30.7^{\mathrm{c}}$ \\
\hline $\mathrm{SE}$ & 0.79 & 5.9 & 1.25 \\
\hline Treatment effect & NS & 0.07 & 0.0004 \\
\hline Hybrid effect & NS & 0.0001 & $\mathrm{NS}$ \\
\hline Maturity effect & NS & 0.07 & NS \\
\hline Processing effect & NS & NS & NS \\
\hline Hybrid by maturity effect & 0.13 & NS & NS \\
\hline Hybrid by processing effect & NS & NS & NS \\
\hline Maturity by processing effect & NS & NS & NS \\
\hline
\end{tabular}

silage compared with unprocessed corn silage harvested at two-thirds ML stage of maturity (experiment 2; Table 4). Apparent postruminal starch digestibility (approximately 90\%) was greater than ruminal starch digestibility (approximately 68\%). However, a greater amount of the starch in the diet was digested in the rumen $(\sim 70 \%)$ versus postruminally $(\sim 30 \%)$. Other studies (Doggett, 1998; Harrison et al., 1998; Bal et al., $2000 \mathrm{~b}$ ), using the macro in situ technique, reported an increase in ruminal starch digestibility due to mechanical processing of corn silage. An in vivo study (RojasBourrillon et al., 1987) demonstrated that mechanical processing of corn silage increased ruminal $(P<0.01)$ and postruminal digestion of total $\alpha$-glucosides (starch) compared with control silage.

Starch apparently digested in the total tract was not affected by maturity or mechanical processing of corn silage in experiment 1 , and was affected by maturity and mechanically processing of corn silage in experiment 2 (Table 4). Processing corn silage enhanced digestion of starch in the total tract compared to unprocessed corn silage diets (experiment $2 ; P<0.0001$; Table 4). There was a hybrid-by-maturity interaction for total tract starch digestibility (Table 4; experiment 2). For hybrid 3845 in experiment 2 , starch apparently digested in the total tract declined $(P<0.003)$ as maturity advanced from one-third ML to two-thirds ML and BL (Table 4). There was a maturity by processing interaction, and at advanced stages of maturity, processing enhanced starch digestion to a greater extent than with less mature silages [experiment 2, two-thirds ML and $\mathrm{BL}(P<0.008)]$.

The difference in total tract starch digestibility between experiments can be partially explained by parti- 
cle size of the corn silage. In experiment 1 , the TLC was $6.4 \mathrm{~mm}$, and in experiment 2, the TLC was 12.7 $\mathrm{mm}$. The short particle size in experiment 1 tended to minimize differences between processed and unprocessed corn silages which may have led to no difference being detected in total tract starch digestibility. In experiment 2 , the particle size of the corn silage was longer; therefore, mechanical processing had a greater potential to alter the physical characteristics of the corn silage that may have led to the increase in total tract starch digestibility. Others reported a significant decline in total tract starch digestibility as maturity advanced (Harrison et al., 1996; Bal et al., 1997), or when medium to physiologically mature corn silage was not mechanically processed (Rojas-Bourrillon et al., 1987; Young et al., 1998, Dhiman et al., 2000, and Weiss and Wyatt, 2000; Bal et al., 2000a).

Fiber intake and digestion. Intake of NDF $(\mathrm{kg} / \mathrm{d})$ was affected by hybrid of corn silage in the diet (experiment 2; Table 6). Cows fed diets containing hybrid 3845 consumed approximately $0.43 \mathrm{~kg}$ more NDF/d than cows fed hybrid Quanta $(P<0.02$; Table 6$)$. The increase in NDF intake was mainly associated with a greater NDF concentration $(P<0.01$; Johnson et al., 2002; Table 3 ) for the diet containing hybrid 3845 because DMI (Table 5) was similar between hybrids. The greater NDF concentration for the diet containing hybrid 3845 corn silage was related to the greater $(P<0.0001) \mathrm{NDF}$ concentration in hybrid 3845 corn silage $(44.3 \%)$ compared with hybrid Quanta corn silage (41.2\%; Johnson et al., 2002).

Ruminal NDF digestibility tended to increase as maturity advanced (Table 6). In experiment 1, cows fed diets containing corn silage harvested at two-thirds ML $(57.7 \%)$ had significantly greater $(P<0.05)$ ruminal NDF digestibility than cows fed diets containing corn silage harvested at hard dough $(53.1 \%)$ and one-third ML (51.3\%; Table 6). In experiment 2, cows fed diets containing corn silage harvested at one-third ML $(34.1 \%)$ tended to have lower $(P<0.10)$ ruminal NDF digestibility than cows fed diets containing corn silage harvested at advanced maturities (two-thirds ML, 38.3\%; BL, 39.8\%; Table 6]. These results are contradictory to published data. As maturity of corn silage advanced from dent to black layer, ruminal in situ NDF digestibility decreased (Doggett, 1998).

Neutral detergent fiber digestion postruminally was not different from zero in experiment 1 and for hybrid 3845 in experiment 2 (Table 6 ). The negative NDF digestion postruminally is possible; however, it is probably an artifact of the assay. Crocker et al. (1998) demonstrated that neutral detergent insoluble ash differed greatly among different digestion sites, and this accounted for negative NDF digestibilities. Apparent ru- minal NDF digestibility was significantly lower $(P<$ 0.007 ), and apparent postruminal NDF digestibility was significantly greater $(P<0.0004)$ for cows fed diets containing hybrid Quanta compared to cows fed diets containing hybrid 3845 in experiment 2 (Table 6).

Cows fed diets containing hybrid Quanta corn silage (45.4\%) had significantly greater $(P<0.001)$ total tract NDF digestibility than cows fed hybrid 3845 corn silage diets $(40.1 \%)$. Total tract NDF digestibility significantly increased $(P<0.001)$ as maturity advanced (hard dough, $49.4 \%$ and one-third ML, $49.4 \%$ to two-thirds ML, 53.2\%) in experiment 1 , and total tract NDF digestibility tended to increase $(P<0.09)$ as maturity advanced from one-third ML to two-thirds ML and BL in experiment 2 (Table 6). This is contradictory to published data that reported a decrease in total tract NDF digestibility as maturity advanced (Bal et al., 1997). Total tract NDF digestibility tended to be greater $(P<$ $0.09)$ for cows fed diets containing unprocessed (51.4\%) corn silage compared to processed $(50.0 \%)$ corn silage diets in experiment 1 (Table 6). However, in experiment 2 , cows fed diets containing processed corn silage had greater total tract NDF digestibility $(P<0.04$; Table 6). Others (Rojas-Bourrillon et al., 1987; Young et al., 1998; and Weiss and Wyatt, 2000; Bal et al., 2000a) have reported no difference or a decline (Dhiman et al., 2000 ) in total tract NDF digestibility between processed or unprocessed corn silage-based diets.

Ether extract intake and digestion. Hybrid, maturity, and processing all affected ether extract intake (Table 7). The differences in intake were usually influenced by the concentration of ether extract (crude fat) in the respective TMR (Tables 2 and 3). Total tract ether extract digestibility was affected by maturity of corn silage in experiments 1 and 2 (hybrid by maturity interaction; Table 7). Total tract ether extract digestibility was lower for cows fed diets containing corn silage harvested at the middle maturity compared to the other maturities in experiment $1(P<0.03)$ and lower at the middle maturity compared to the early maturity for hybrid 3845 in experiment $2(P<0.02$; Table 7$)$. The opposite trend was observed for cows fed diets containing hybrid Quanta corn silage in experiment $2(P$ $<0.02$; Table 7). The differences in total tract ether extract (crude fat) digestibility are most likely related to the concentration of ether extract in the TMR (Tables 2 and 3) and orts because ether extract excreted in the feces was not affected by maturity of corn silage. Others (Huber et al., 1965) reported no significant difference in total tract ether extract digestibility due to maturity. However, in the second year of one study (Huber et al., 1965), there was onea fairly substantial decline (8.2 percentage units) in total tract ether extract digestibil- 
Table 6. Intake and digestion of NDF (DM basis) for experiments 1 and 2 .

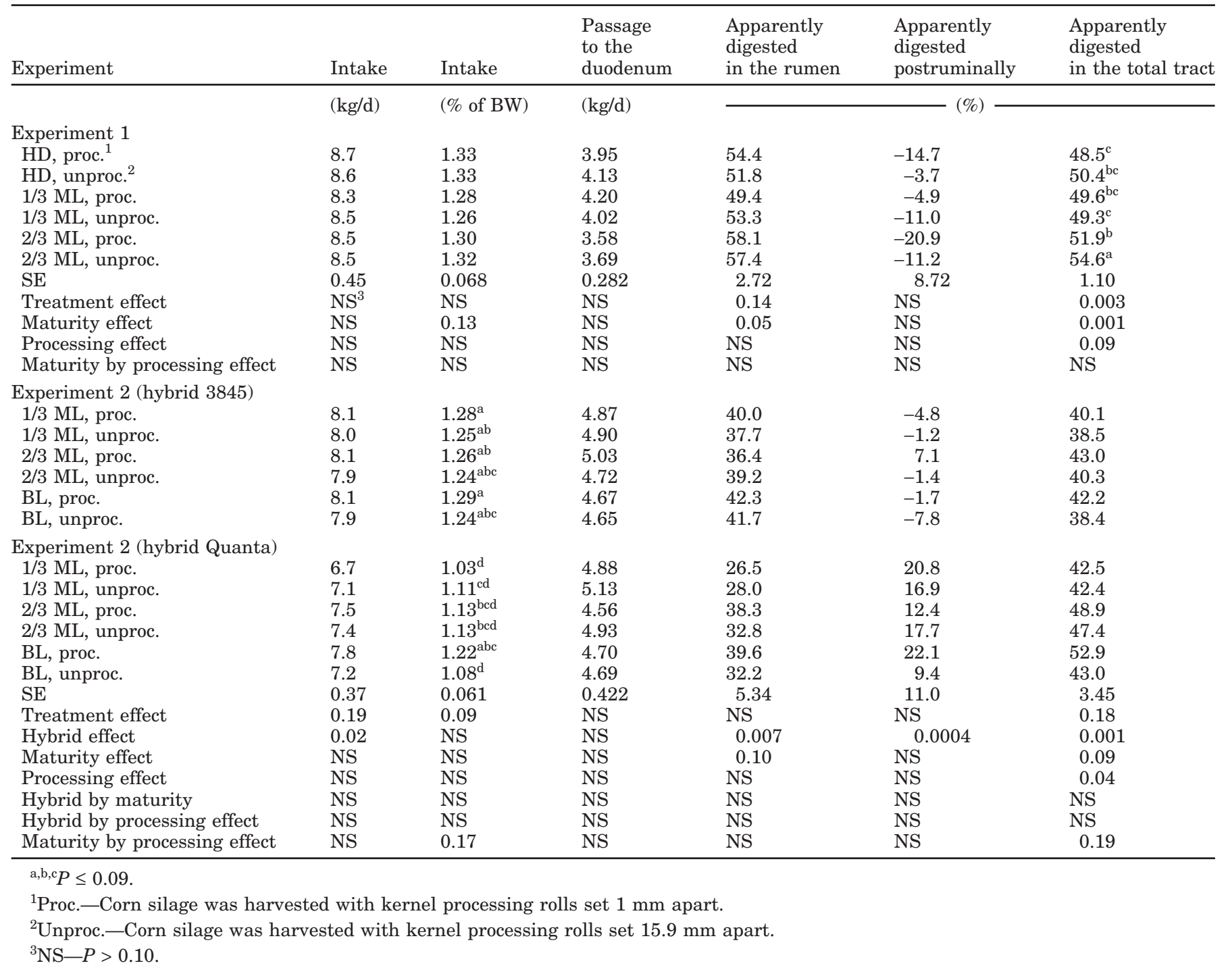

ity as the corn matured from soft dough (25.4\% DM) to medium dough $(30.3 \% \mathrm{DM})$.

Total tract ether extract digestibility was affected by processing method (Table 7 ). In experiment 1 , cows fed diets containing unprocessed corn silage (92\%) had significantly greater $(P<0.003)$ total tract ether extract digestibility compared with processed corn silage diets (90.8\%; Table 7). In experiment 2, total tract ether extract digestibility tended to be greater $(P<0.09)$ for cows fed diets containing processed corn silage (90.5\%) compared to unprocessed corn silage (89.8\%). Weiss and Wyatt (2000) reported that cows fed processed conventional corn silage had 3.8 percentage units greater total tract fat digestibility than cows fed the unprocessed corn silage diet. The difference reported by Weiss and Wyatt (2000) was greater than the differences observed in these experiments. Therefore, although significant differences due to maturity and processing were reported across experiments, the differences were relatively small and probably had limited biological impact.

\section{Energy Estimates of TMR and Energy Requirements}

Methane and urinary energy output. Estimated methane energy was not significantly affected by maturity, processing, or maturity by processing interactions in experiment 1 (Table 8). There was an effect of treatment on estimated methane energy production in experiment $2(P<0.06)$; however, there were no significant effects of hybrid, maturity, or processing on estimated methane energy production (Table 8).

Estimated urinary energy was not significantly affected by maturity, processing, or maturity by processing interactions in both experiments (Table 8). 
Table 7. Intake and digestion of ether extract (DM basis) in experiments 1 and 2 .

\begin{tabular}{|c|c|c|}
\hline Experiement & Intake & $\begin{array}{l}\text { Apparently } \\
\text { digested } \\
\text { in the total } \\
\text { tract }\end{array}$ \\
\hline & $(\mathrm{kg} / \mathrm{d})$ & $(\%)$ \\
\hline \multicolumn{3}{|l|}{ Experiment 1} \\
\hline HD, proc. ${ }^{1}$ & 1.03 & $90.7^{\mathrm{b}}$ \\
\hline HD, unproc. ${ }^{2}$ & 1.17 & $92.3^{\mathrm{a}}$ \\
\hline 1/3 ML, proc. & 1.00 & $90.4^{\mathrm{b}}$ \\
\hline $1 / 3 \mathrm{ML}$, unproc. & 1.01 & $90.9^{\mathrm{b}}$ \\
\hline 2/3 ML, proc. & 1.01 & $91.2^{\mathrm{b}}$ \\
\hline 2/3 ML, unproc. & 1.19 & $92.7^{\mathrm{a}}$ \\
\hline SE & 0.08 & 0.50 \\
\hline Treatment effect & $\mathrm{NS}^{3}$ & 0.006 \\
\hline Maturity effect & 0.04 & 0.03 \\
\hline Processing effect & 0.001 & 0.003 \\
\hline Maturity by processing effect & 0.11 & NS \\
\hline \multicolumn{3}{|l|}{ Experiment 2 (Hybrid 3845 ) } \\
\hline 1/3 ML, proc. & $1.55^{\mathrm{a}}$ & 91.5 \\
\hline $1 / 3 \mathrm{ML}$, unproc. & $1.33^{\mathrm{bc}}$ & 90.3 \\
\hline 2/3 ML, proc. & $1.32^{\mathrm{bc}}$ & 89.8 \\
\hline 2/3 ML, unproc. & $1.31^{\mathrm{bc}}$ & 89.0 \\
\hline BL, proc. & $1.32^{\mathrm{bc}}$ & 89.6 \\
\hline $\mathrm{BL}$, unproc. & $1.24^{\mathrm{c}}$ & 90.0 \\
\hline \multicolumn{3}{|l|}{ Experiment 2 (Hybrid Quanta) } \\
\hline $1 / 3 \mathrm{ML}$, proc. & $1.08^{\mathrm{d}}$ & 90.5 \\
\hline $1 / 3 \mathrm{ML}$, unproc. & $1.09^{\mathrm{d}}$ & 89.3 \\
\hline $2 / 3 \mathrm{ML}$, proc. & $1.34^{\mathrm{b}}$ & 91.6 \\
\hline 2/3 ML, unproc. & $1.30^{\mathrm{bc}}$ & 91.0 \\
\hline BL, proc. & $1.05^{\mathrm{d}}$ & 90.4 \\
\hline BL, unproc. & $1.02^{\mathrm{d}}$ & 89.6 \\
\hline $\mathrm{SE}$ & 0.044 & 0.90 \\
\hline Treatment effect & 0.0001 & NS \\
\hline Hybrid effect & 0.0001 & 0.18 \\
\hline Maturity effect & 0.0001 & NS \\
\hline Processing effect & 0.008 & 0.09 \\
\hline Hybrid by maturity effect & 0.0001 & 0.02 \\
\hline Hybrid by processing effect & 0.04 & NS \\
\hline Maturity by processing effect & NS & NS \\
\hline
\end{tabular}

${ }^{\mathrm{a}, \mathrm{b}, \mathrm{c}} P \leq 0.09$

${ }^{1}$ Proc.-Corn silage was harvested with kernel processing rolls set $1 \mathrm{~mm}$ apart.

${ }^{2}$ Unproc.-Corn silage was harvested with kernel processing rolls set $15.9 \mathrm{~mm}$ apart.

${ }^{3} \mathrm{NS}-P>0.10$.

However, output of urinary energy was greater $(P<$ 0.0001) for cows fed diets containing hybrid Quanta corn silage than for cows fed hybrid 3845 corn silagebased diets in experiment 2 (Table 8 ). The greater urinary energy output may have been partially related to greater $(P<0.0001)$ concentrations of $\mathrm{CP}$ in the diet and greater $(P<0.0001)$ excretion of $\mathrm{N}$ in the urine for hybrid Quanta (16.2\% diet CP) compared to hybrid 3845 (15.0\% diet CP; Table 3 ) because urinary energy output was estimated from the concentration of nitrogen in urine.

Digestible energy of TMR. The concentration and intake of DE was affected by maturity in experiment 1 . The $\mathrm{DE}$ concentration $(\mathrm{Mcal} / \mathrm{kg}$ ) was significantly lower $(P<0.004)$ for diets containing corn silage harvested at two-thirds ML (2.92 Mcal $/ \mathrm{kg})$ compared to one-third ML (3.07 Mcal $/ \mathrm{kg}$ ) and hard dough (3.07 Mcal/ $\mathrm{kg}$; experiment 1 ; Table 8). The amount of DE consumed $(\mathrm{Mcal} / \mathrm{d})$ was greater $(P<0.09)$ for cows fed diets containing corn silage harvested at hard dough compared to two-thirds ML (experiment 1; Table 8). In experiment 1 , the greater amount of $\mathrm{DE}$ consumed (Mcal/d) at hard dough maturity was related to the greater intake of gross energy [Mcal/d; data not shown] compared to twothirds ML.

Other studies have evaluated the effect of maturity of corn silage on energy concentration and digestibility of the diet (Huber et al., 1965; Buck et al., 1969; Goering et al., 1969; St. Pierre et al., 1987). In these studies, corn silage was typically the only forage provided and usually made up a large portion of the diet DM (70 to $90 \%)$. Varying results were observed, and statistical significance was achieved only in Trial 1 of the study conducted by Goering et al. (1969). A summary of the four research studies indicates that decreases in energy digestibility were very gradual with increasing maturity estimated by DM concentration of the corn silage. However, there was a trend of decreasing energy digestibility with increasing maturity that followed trends observed in experiment 1 and for hybrid 3845 in experiment 2.

Mechanical processing of corn silage affected energy digestibility (Table 8). Digestible energy, as a percent of gross energy, was significantly lower $(P<0.03)$ for cows fed processed corn silage diets in experiment 1 . The decrease in total tract NDF $(P<0.09$; Table 6$)$, ether extract $(P<0.003$; Table 7$)$, and $\mathrm{CP}(P<0.03$; data not shown) digestibilities for cows fed processed corn silage diets mainly contributed to the decline in $\mathrm{DE}$ (\% of gross energy) in experiment 1.

Two older studies have evaluated the effect of processing corn silage on energy content (Buck et al., 1969 and Rojas-Bourrillon et al., 1987) in animal digestion studies. In both trials of Buck et al. (1969), recutting corn silage had no beneficial effect on energy digestibility. No significant difference was observed between 'regular cut' and 'recut' silages because the difference in indigestibility of available carbohydrates was not large enough to result in a significant change in energy digestibility (Buck et al., 1969). Rojas-Bourrillon et al. (1987) reported no significant difference in gross energy digestibility at the rumen, small intestine, large intestine, or in the total tract. The authors (Rojas-Bourrillon et al., 1987) concluded that no difference in gross energy digestibility was observed because of the opposing effect of increased $\alpha$-glucoside digestibility and decreased digestibility of fiber when cows were fed processed corn silage diets vs. unprocessed corn silage diets. 
Table 8. Energy estimates of TMR fed to cows in experiments 1 and 2.

\begin{tabular}{|c|c|c|c|c|c|c|c|c|c|c|c|}
\hline Experiment & $\mathrm{TDN}^{1}$ & $\mathrm{DE}^{2}$ & $\mathrm{DE}$ & $\mathrm{DE}$ & $\mathrm{UE}^{3}$ & $\begin{array}{l}\text { Methane }{ }^{4} \\
\text { energy }\end{array}$ & $\mathrm{ME}^{5}$ & $\mathrm{ME}$ & $\mathrm{ME}$ & $\mathrm{NE}_{\mathrm{L}}{ }^{6}$ & $\mathrm{NE}_{\mathrm{L}}$ \\
\hline & $(\%)$ & (Mcal/d) & (Mcal/kg) & (\% of gross energy) & $\longrightarrow$ & $-(\mathrm{Mcal} / \mathrm{d})$ & - & $(\mathrm{Mcal} / \mathrm{kg})$ & $(\%$ of $\mathrm{DE})$ & $(\mathrm{Mcal} / \mathrm{d})$ & (Mcal/kg) \\
\hline \multicolumn{12}{|l|}{ Experiment 1} \\
\hline $\mathrm{HD}$, proc. ${ }^{7}$ & $66.0^{\mathrm{c}}$ & 65.7 & $3.03^{\mathrm{ab}}$ & 66.4 & 4.1 & 5.6 & 56.0 & $2.58^{\mathrm{ab}}$ & $85.0^{\mathrm{a}}$ & 32.5 & $1.50^{\mathrm{c}}$ \\
\hline HD, unproc. ${ }^{8}$ & $69.0^{\mathrm{ab}}$ & 67.5 & $3.11^{\mathrm{a}}$ & 68.6 & 4.1 & 5.6 & 57.7 & $2.66^{\mathrm{a}}$ & $85.5^{\mathrm{a}}$ & 34.1 & $1.57^{\mathrm{ab}}$ \\
\hline 1/3 ML, proc. & $67.4^{\mathrm{bc}}$ & 63.7 & $3.06^{\mathrm{a}}$ & 66.4 & 4.0 & 5.4 & 54.3 & $2.61^{\mathrm{a}}$ & $85.0^{\mathrm{a}}$ & 32.0 & $1.53^{\mathrm{bc}}$ \\
\hline 1/3 ML, unproc. & $68.0^{\mathrm{ab}}$ & 65.7 & $3.08^{\mathrm{a}}$ & 68.6 & 4.2 & 5.5 & 56.1 & $2.63^{\mathrm{a}}$ & $85.4^{\mathrm{a}}$ & 33.1 & $1.55^{\mathrm{ab}}$ \\
\hline 2/3 ML, proc. & $68.0^{\mathrm{ab}}$ & 60.9 & $2.90^{\mathrm{c}}$ & 66.8 & 4.1 & 5.5 & 51.3 & $2.43^{\mathrm{c}}$ & $83.9^{\mathrm{b}}$ & 32.5 & $1.55^{\mathrm{ab}}$ \\
\hline $2 / 3 \mathrm{ML}$, unproc. & $69.3^{\mathrm{a}}$ & 60.8 & $2.94^{\mathrm{bc}}$ & 67.5 & 4.1 & 5.6 & 51.1 & $2.47^{\mathrm{bc}}$ & $84.0^{\mathrm{b}}$ & 32.7 & $1.58^{\mathrm{a}}$ \\
\hline $\mathrm{SE}$ & 0.82 & 2.83 & 0.05 & 1.09 & 0.22 & 0.23 & 2.51 & 0.05 & 0.32 & 1.47 & 0.021 \\
\hline Treatment effect & 0.05 & NS & 0.02 & NS & NS & NS & NS & 0.01 & 0.002 & $\mathrm{NS}$ & 0.06 \\
\hline Maturity effect & $\mathrm{NS}^{9}$ & 0.09 & 0.004 & NS & NS & NS & 0.05 & 0.002 & 0.0002 & NS & NS \\
\hline Processing effect & 0.01 & NS & NS & 0.05 & NS & NS & NS & NS & NS & NS & 0.02 \\
\hline Maturity by processing effect & NS & NS & NS & $\mathrm{NS}$ & NS & NS & NS & NS & NS & NS & NS \\
\hline \multicolumn{12}{|l|}{ Experiment 2 (hybrid 3845 ) } \\
\hline 1/3 ML, proc. & 71.6 & $76.2^{\mathrm{a}}$ & $3.06^{\mathrm{abc}}$ & 66.9 & $3.1^{\mathrm{cd}}$ & $5.9^{\mathrm{a}}$ & $67.2^{\mathrm{a}}$ & $2.70^{\mathrm{abc}}$ & $88.2^{\mathrm{a}}$ & $40.7^{\mathrm{a}}$ & 1.63 \\
\hline 1/3 ML, unproc. & 69.8 & $76.9^{\mathrm{a}}$ & $3.17^{\mathrm{a}}$ & 68.3 & $3.2^{\mathrm{cd}}$ & $5.8^{\mathrm{ab}}$ & $67.9^{\mathrm{a}}$ & $2.80^{\mathrm{a}}$ & $88.4^{\mathrm{a}}$ & $38.6^{\mathrm{ab}}$ & 1.59 \\
\hline 2/3 ML, proc. & 71.2 & $71.3^{\mathrm{a}}$ & $3.01^{\mathrm{abcd}}$ & 66.5 & $3.0^{\mathrm{cd}}$ & $5.9^{\mathrm{ab}}$ & $62.4^{\mathrm{a}}$ & $2.63^{\mathrm{abc}}$ & $87.5^{\mathrm{abc}}$ & $38.5^{\mathrm{ab}}$ & 1.62 \\
\hline 2/3 ML, unproc. & 69.2 & $71.1^{\mathrm{a}}$ & $2.91^{\mathrm{cd}}$ & 64.5 & $3.2^{\text {cd }}$ & $5.9^{\mathrm{ab}}$ & $62.0^{\mathrm{a}}$ & $2.54^{\text {cd }}$ & $87.2^{\mathrm{abc}}$ & $38.5^{\mathrm{ab}}$ & 1.57 \\
\hline $\mathrm{BL}$, proc. & 69.8 & $72.8^{\mathrm{a}}$ & $3.03^{\text {abc }}$ & 66.4 & $2.9^{\mathrm{d}}$ & $5.7^{\mathrm{abc}}$ & $64.2^{\mathrm{a}}$ & $2.67^{\mathrm{abc}}$ & $88.1^{\mathrm{ab}}$ & $38.3^{\mathrm{ab}}$ & 1.59 \\
\hline BL, unproc. & 68.2 & $70.5^{\mathrm{a}}$ & $2.93^{\mathrm{bcd}}$ & 64.7 & $3.0^{\mathrm{d}}$ & $5.7^{\mathrm{abc}}$ & $61.8^{\mathrm{a}}$ & $2.57^{\mathrm{bcd}}$ & $87.6^{\mathrm{ab}}$ & $37.3^{\mathrm{ab}}$ & 1.55 \\
\hline \multicolumn{12}{|l|}{ Experiment 2 (hybrid Quanta) } \\
\hline 1/3 ML, proc. & 66.3 & $62.4^{\mathrm{b}}$ & $2.85^{\mathrm{d}}$ & 64.4 & $4.0^{\mathrm{ab}}$ & $5.1^{\mathrm{d}}$ & $53.4^{\mathrm{b}}$ & $2.43^{\mathrm{d}}$ & $85.3^{\mathrm{d}}$ & $32.9^{\mathrm{c}}$ & 1.50 \\
\hline 1/3 ML, unproc. & 67.0 & $70.7^{\mathrm{a}}$ & $3.00^{\mathrm{abcd}}$ & 65.9 & $4.4^{\mathrm{a}}$ & $5.5^{\mathrm{bc}}$ & $60.9^{\mathrm{a}}$ & $2.59^{\text {cd }}$ & $86.1^{\mathrm{cd}}$ & $35.8^{\mathrm{bc}}$ & 1.52 \\
\hline 2/3 ML, proc. & 71.0 & $74.8^{\mathrm{a}}$ & $3.13^{\mathrm{a}}$ & 69.0 & $3.8^{\mathrm{b}}$ & $5.7^{\mathrm{ab}}$ & $65.4^{\mathrm{a}}$ & $2.73^{\mathrm{ab}}$ & $87.4^{\mathrm{ab}}$ & $38.8^{\mathrm{ab}}$ & 1.62 \\
\hline 2/3 ML, unproc. & 70.2 & $75.6^{\mathrm{a}}$ & $3.11^{\mathrm{ab}}$ & 68.6 & $3.9^{\mathrm{ab}}$ & $5.5^{\mathrm{abc}}$ & $66.3^{\mathrm{a}}$ & $2.72^{\text {abc }}$ & $87.3^{\mathrm{abc}}$ & $38.9^{\mathrm{ab}}$ & 1.60 \\
\hline $\mathrm{BL}$, proc. & 70.1 & $76.1^{\mathrm{a}}$ & $3.12^{\mathrm{a}}$ & 69.6 & $3.6^{\mathrm{bc}}$ & $5.9^{\mathrm{a}}$ & $66.6^{\mathrm{a}}$ & $2.73^{\text {abc }}$ & $87.3^{\text {abc }}$ & $38.9^{\mathrm{ab}}$ & 1.60 \\
\hline BL, unproc. & 66.9 & $70.4^{\mathrm{a}}$ & $3.02^{\mathrm{abc}}$ & 66.6 & $3.9^{\mathrm{ab}}$ & $5.4^{\text {cd }}$ & $61.2^{\mathrm{a}}$ & $2.62^{\text {abc }}$ & $86.8^{\mathrm{bc}}$ & $35.4^{\mathrm{bc}}$ & 1.52 \\
\hline $\mathrm{SE}$ & 1.54 & 3.45 & 0.081 & 1.77 & 0.26 & 0.19 & 3.32 & 0.084 & 0.607 & 1.73 & 0.038 \\
\hline Treatment effect & 0.11 & 0.08 & 0.06 & NS & 0.007 & 0.06 & 0.07 & 0.05 & 0.03 & 0.09 & 0.11 \\
\hline Hybrid effect & 0.01 & NS & NS & NS & 0.0001 & 0.11 & NS & NS & 0.02 & NS & 0.01 \\
\hline Maturity effect & 0.07 & NS & NS & NS & 0.19 & NS & NS & NS & NS & NS & 0.07 \\
\hline Processing effect & 0.04 & NS & NS & NS & 0.19 & NS & NS & NS & NS & NS & 0.03 \\
\hline Hybrid by maturity effect & 0.02 & 0.004 & 0.0002 & 0.005 & NS & 0.17 & 0.003 & 0.0002 & 0.004 & 0.03 & 0.02 \\
\hline Hybrid by processing effect & NS & NS & NS & NS & NS & NS & NS & NS & NS & NS & NS \\
\hline Maturity by processing effect & NS & 0.15 & 0.02 & 0.12 & NS & NS & 0.16 & 0.03 & NS & NS & NS \\
\hline
\end{tabular}

a,b,c,d $P \leq 0.09$.

${ }^{1} \mathrm{TDN}-$ Total digestible nutrients. TDN $=$ digestible $\mathrm{CP}+$ digestible nonfiber carbohydrates + digestible NDF $+($ digestible ether extract $\times 2.25)$.

${ }^{2} \mathrm{DE}$-Digestible energy (Mcal/d, Mcal/kg DMI, and \%) was calculated from measured gross energy and fecal energy values collected during the digestion study.

${ }^{3}$ Urinary energy—estimated from urinary nitrogen values [urinary energy (Kcal/kg) $=23.8+(125.0 \times$ nitrogen $)$; Elliot and Loosli, 1959].

${ }^{4}$ Methane energy—estimated from intake of carbohydrate fractions. Methane $(\mathrm{Mcal} / \mathrm{d})=0.814+[0.122 \times$ nonfiber carbohydrates $(\mathrm{kg} / \mathrm{d})]+[0.415 \times \mathrm{hemicellulose}(\mathrm{kg} / \mathrm{d})]+$ $[0.633 \times$ cellulose $(\mathrm{kg} / \mathrm{d})]$. Moe and Tyrell, 1979

을 $\quad{ }^{5} \mathrm{ME}-$ Metabolizable energy (Mcal/d, Mcal/kg DMI, and \%) estimated from gross energy, fecal energy, urinary energy, and methane energy.

${ }^{6} \mathrm{NE}_{\mathrm{L}}-\mathrm{Net}$ energy of lactation $(\mathrm{Mcal} / \mathrm{d}$ and Mcal/kg DMI) predicted from TDN (digestible $\mathrm{CP}+$ digestible nonfiber carbohydrates + digestible NDF $+($ digestible ether extract $\times 2.25)) . \mathrm{NE}_{\mathrm{L}}(\mathrm{Mcal} / \mathrm{kg})=(0.0245 \times \mathrm{TDN})-0.12$.

Z $\quad{ }^{7}$ Proc.-Corn silage was harvested with kernel processing rolls set $1 \mathrm{~mm}$ apart.

$\Rightarrow \quad{ }^{8}$ Unproc.-Corn silage was harvested with kernel processing rolls set $15.9 \mathrm{~mm}$ apart.

${ }^{9} \mathrm{NS}-P>0.10$ 
Metabolizable energy of TMR. Estimated metabolizable energy (ME) of the diets followed similar trends as DE measurements because they were estimated from $\mathrm{DE}$. The amount of ME in the diet was significantly affected by maturity in experiment 1 . Metabolizable energy intake $(\mathrm{Mcal} / \mathrm{d})$ was greater $(P<0.05)$ at early maturities (hard dough and one-third ML) compared with the advanced maturity (two-thirds ML; Table 8). Also, in experiment 1 , diets containing corn silage harvested at two-thirds ML had the lowest concentration $[\mathrm{Mcal} / \mathrm{kg} ; P<0.002]$ and digestibility of $\mathrm{ME}[\%$ of $\mathrm{DE}$; $P<0.0002$ ], compared with one-third ML and hard dough stages of maturity (Table 8).

Converting fibrous carbohydrates to energy is less efficient than converting nonfibrous sources of carbohydrates to energy in the rumen due to the metabolic pathways that each carbohydrate source uses. Greater amounts of methane are produced when fiber is digested. In experiment 1 , there were greater levels of fiber and lower levels of nonfiber carbohydrate sources fed compared to experiment 2 (Tables 2 and 3 ). Therefore, the assumption could be made that the diets fed in experiment 1 would produce a greater amount of methane than diets fed in experiment 2 .

Some of the $\mathrm{N}$ consumed by the cow is excreted in urine and not used as an energy source. When the level of $\mathrm{N}$ in the diet exceeds the $\mathrm{N}$ requirements of the cow a greater amount will be excreted in the urine. The dietary CP concentration was greater in experiment 1 than experiment 2 (Tables 2 and 3). Therefore, the assumption could be made that a greater amount of urinary energy would be excreted in experiment 1 than experiment 2 (Table 8 ). In experiment 2 , the dietary CP concentration $(P<0.0001$; Table 3$)$ and urinary $\mathrm{N}$ output $(P<0.0001)$ were greater for hybrid Quanta than hybrid 3845 .

Based on the above assumptions, ME as a \% of DE should be lower in experiment 1 than experiment 2, and $\mathrm{ME}$ as a \% of DE should be lower for hybrid Quanta than hybrid 3845 in experiment 2 . In experiment $1, \mathrm{ME}$ as a percent of $\mathrm{DE}$ averaged $84.8 \%$, and in experiment 2, ME as a percent of $\mathrm{DE}$ averaged $87.3 \%$ (Table 8). The lower $\mathrm{ME}$ as a \% of $\mathrm{DE}$ was mainly attributed to greater urinary energy output in experiment 1 because methane output was actually greater in experiment 2 than in experiment 1 (Table 8). In experiment $2, \mathrm{ME}$ as a percent of DE was significantly lower $(P<0.02)$ for cows fed diets containing hybrid Quanta corn silage (86.9\%) than hybrid 3845 (87.7\%; Table 8).

Total digestible nutrients and $N_{L}$ concentration of TMR. Total digestible nutrients (TDN) were calculated two ways in this paper. An equation was used that converts measured DE into TDN [TDN $=\mathrm{DE}$ (Mcal/kg)/0.04409; NRC, 1989]. Total digestible nutri- ents (TDN) were also measured using the digestion coefficients and nutrient concentration in TMR [measured TDN = digestible CP + digestible nonfiber carbohydrates + digestible NDF + (digestible ether extract $x$ 2.25)]. Total digestible nutrients (TDN) measured from nutrient digestibilities $(68.0,69.9$, and $68.2 \%$, respectively) were similar to TDN calculated from DE (measured via bomb calorimetry; $68.5,68.5$, and $68.7 \%$, respectively) in experiment 1 and for hybrids 3845 and Quanta in experiment 2, respectively.

Measured TDN (measured from nutrient digestibilities) and $\mathrm{NE}_{\mathrm{L}}$ concentrations were affected by maturity of corn silage in experiment 2 (Table 8). There was a hybrid by maturity interaction, and diets containing hybrid Quanta corn silage harvested at two-thirds ML had significantly greater TDN $(P<0.02)$ and $\mathrm{NE}_{\mathrm{L}}$ concentrations $(P<0.02)$ than diets containing hybrid Quanta corn silage harvested at other maturities in experiment 2 (Table 8). For hybrid Quanta in experiment 2, the increase in $\mathrm{TDN}$ and $\mathrm{NE}_{\mathrm{L}}$ concentrations for diets containing corn silage harvested at two-thirds ML was partially related to increased total tract ether extract digestibility $(P<0.02$; Table 6$)$.

Mechanical processing had a significant effect on measured TDN and $\mathrm{NE}_{\mathrm{L}}$ concentrations in experiments 1 and 2 (Table 8). The measured TDN $(P<0.01)$ and $\mathrm{NE}_{\mathrm{L}}$ concentrations $(P<0.02)$ were greater for diets containing unprocessed corn silage in experiment 1 and lower (TDN, $P<0.04 ; \mathrm{NE}_{\mathrm{L}}, P<0.03$ ) for diets containing unprocessed corn silage in experiment 2 (Table 8). The greater TDN and $\mathrm{NE}_{\mathrm{L}}$ concentrations for diets containing unprocessed corn silage in experiment 1 can be explained by the increased total tract NDF $(P<0.09$; Table 6), ether extract $(P<0.003$; Table 7$)$, and CP $(P$ $<0.03$ ) digestibilities for cows fed unprocessed cornsilage diets. The lower TDN and $\mathrm{NE}_{\mathrm{L}}$ concentrations for diets containing unprocessed corn silage in experiment 2 can be attributed to lower total tract starch $(P$ $<0.0001$; Table 4$)$ and NDF $(P<0.04$; Table 6$)$ digestibilities for cows fed unprocessed corn silage diets.

The exact reason for these results in experiment 1 is unknown. However, the authors speculate that it was partially related to the short particle size of the corn silages fed in experiment 1 (Johnson et al., 2002), which could have increased the rate of passage, and, therefore, decreased the extent of digestibility. This would be true especially for diets containing processed corn silage because the particle size was slightly shorter than the unprocessed corn silage (experiment 1; Johnson et al., 2002). Total digestible nutrients (TDN) and $\mathrm{NE}_{\mathrm{L}}$ concentrations $(\mathrm{Mcal} / \mathrm{kg}$ ) were, on average, 2.2 and $2.6 \%$ greater for TMR containing processed corn silage in experiment 2. Weiss and Wyatt (2000) reported that measured TDN (\%) and $\mathrm{NE}_{\mathrm{L}}$ concentrations (Mcal/kg; 
Table 9. Energy balance in experiments 1 and 2 .

\begin{tabular}{|c|c|c|c|c|c|}
\hline Experiment & $\begin{array}{l}\text { Energy intake } \\
\text { above maintenance }{ }^{1}\end{array}$ & $\begin{array}{l}\mathrm{DE} \text { milk }{ }^{2}+ \\
\text { maintenance }\end{array}$ & $\begin{array}{l}\text { DE intake } \\
\text { - required }\end{array}$ & $\begin{array}{l}\mathrm{NE}_{\mathrm{L}} \text { milk }^{3}+ \\
\text { maintenance }\end{array}$ & $\begin{array}{l}\mathrm{NE}_{\mathrm{L}} \text { intake } \\
- \text { required }\end{array}$ \\
\hline & & & - & 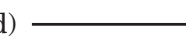 & 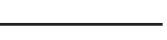 \\
\hline \multicolumn{6}{|l|}{ Experiment 1} \\
\hline HD, unproc. ${ }^{5}$ & 3.3 & 54.9 & $12.6^{\mathrm{a}}$ & 28.6 & 5.6 \\
\hline 1/3 ML, proc. & 3.1 & 52.7 & $11.0^{\mathrm{ab}}$ & 27.5 & 4.5 \\
\hline 1/3 ML, unproc. & 3.1 & 56.5 & $9.3^{\mathrm{ab}}$ & 29.4 & 3.6 \\
\hline $\mathrm{SE}$ & 0.21 & 3.00 & 3.10 & 1.41 & 1.49 \\
\hline Treatment effect & $\mathrm{NS}^{8}$ & NS & 0.04 & NS & NS \\
\hline Maturity effect & NS & NS & 0.006 & NS & NS \\
\hline Processing effect & NS & NS & NS & NS & NS \\
\hline Maturity by processing effect & NS & NS & NS & NS & NS \\
\hline \multicolumn{6}{|l|}{ Experiment 2 (hybrid 3845 ) } \\
\hline 1/3 ML, proc. & $4.0^{\mathrm{a}}$ & $68.4^{\mathrm{b}}$ & $7.8^{\mathrm{bcd}}$ & $35.7^{\mathrm{ab}}$ & $5.0^{\text {abcde }}$ \\
\hline \multicolumn{6}{|l|}{ Experiment 2 (hybrid Quanta) } \\
\hline $1 / 3 \mathrm{ML}$, proc. & $3.2^{\mathrm{d}}$ & $59.1^{\mathrm{cd}}$ & $3.3^{\text {cd }}$ & $31.0^{\text {cd }}$ & $1.9^{\mathrm{ef}}$ \\
\hline 1/3 ML, unproc. & $3.5^{\mathrm{bc}}$ & $60.8^{\mathrm{c}}$ & $9.9^{\mathrm{abc}}$ & $31.9^{c}$ & $3.9^{\text {bcdef }}$ \\
\hline 2/3 ML, proc. & $3.7^{\mathrm{abc}}$ & $61.9^{c}$ & $13.0^{\mathrm{ab}}$ & $32.6^{\mathrm{c}}$ & $6.3^{\mathrm{abc}}$ \\
\hline 2/3 ML, unproc. & $3.8^{\mathrm{ab}}$ & $59.5^{\mathrm{cd}}$ & $16.1^{\mathrm{a}}$ & $31.2^{\text {cd }}$ & $7.7^{\mathrm{a}}$ \\
\hline BL, proc. & $3.8^{\mathrm{ab}}$ & $59.6^{\mathrm{cd}}$ & $16.5^{\mathrm{ab}}$ & $31.3^{\text {cd }}$ & $7.6^{\mathrm{ab}}$ \\
\hline $\mathrm{BL}$, unproc. & $3.4^{\mathrm{cd}}$ & $55.9^{\mathrm{d}}$ & $14.5^{\mathrm{ab}}$ & $29.6^{\mathrm{d}}$ & $5.8^{\text {abcd }}$ \\
\hline $\mathrm{SE}$ & 0.16 & 1.86 & 3.78 & 0.93 & 1.82 \\
\hline Treatment effect & 0.03 & 0.0001 & 0.03 & 0.0001 & 0.10 \\
\hline Hybrid effect & NS & 0.0001 & 0.005 & 0.0001 & 0.02 \\
\hline Maturity effect & NS & 0.04 & NS & 0.06 & NS \\
\hline Processing effect & NS & NS & NS & NS & NS \\
\hline Hybrid by maturity effect & 0.02 & NS & 0.009 & NS & 0.05 \\
\hline \multicolumn{6}{|c|}{$\begin{array}{l}{ }^{1} \text { Energy intake above main-Energy intake above maintenance }\left[\mathrm{NE}_{\mathrm{L}} \text { intake }(\mathrm{Mcal} / \mathrm{d}) / \mathrm{NE}_{\mathrm{L}} \text { required for maintenance }(\mathrm{Mcal} / \mathrm{d})\right] \\
\left.{ }^{2} \mathrm{DE} \text { Milk }=\text { digestible energy required to produce milk: } \mathrm{DE} \mathrm{Milk}(\mathrm{Mcal} / \mathrm{d})=1.42 \times 4 \% \mathrm{FCM}(\mathrm{kg} / \mathrm{d})\right] . \mathrm{NRC}(1989) . \mathrm{DE} \text { Maintenance }=\end{array}$} \\
\hline \multicolumn{6}{|c|}{$\begin{array}{l}{ }^{3} \mathrm{NE}_{\mathrm{L}} \text { milk }=\mathrm{NE}_{\mathrm{L}} \text { required to produce milk: }\left\{\mathrm{NE}_{\mathrm{L}} \text { milk }(\mathrm{Mcal} / \mathrm{d})=[9.23 \times \text { milk fat production }(\mathrm{kg} / \mathrm{d})]+[5.71 \times \text { milk protein production }(\mathrm{kg} /\right. \\
\mathrm{d})]+[3.95 \times \text { lactose production }(\mathrm{kg} / \mathrm{d})]\} . \text { Mertens and Dado }(1993) . \mathrm{NE}_{\mathrm{L}} \text { maintenance }=\mathrm{NE}_{\mathrm{L}} \text { required for maintenance: }\left[\mathrm{NE}_{\mathrm{L}} \text { maintenance }\right. \\
\left.(\mathrm{Mcal} / \mathrm{d})=0.08 \times \mathrm{BW}^{0.75}(\mathrm{~kg} / \mathrm{d})\right] \mathrm{NRC}(1989) .\end{array}$} \\
\hline \multicolumn{6}{|c|}{${ }^{4}$ Proc.-Corn silage was harvested with kernel processing rolls set $1 \mathrm{~mm}$ apart. } \\
\hline \multicolumn{6}{|c|}{${ }^{5}$ Unproc.-Corn silage was harvested with kernel processing rolls set $15.9 \mathrm{~mm}$ apart. } \\
\hline
\end{tabular}

calculated from TDN) were approximately 5\% greater $(P<0.07)$ for TMR containing processed corn silage.

Energy requirements of lactating cows. Digestible energy and $\mathrm{NE}_{\mathrm{L}}$ required for milk production and maintenance were estimated from actual production data (Table 9). In experiment 1 , the amount of DE and $\mathrm{NE}_{\mathrm{L}}(\mathrm{Mcal} / \mathrm{d})$ required for milk production and maintenance were not significantly affected by maturity, processing, or maturity by processing interactions (Table $9)$. Digestible energy $(P<0.04)$ and $\mathrm{NE}_{\mathrm{L}}(P<0.06)$ required for milk production and maintenance were lower for cows fed diets containing corn silage harvested at physiological maturity (BL) compared to the earlier maturities in experiment 2 (Table 9). The reason for this is unknown because milk production was not significantly different among cows fed diets differing in maturity of corn silage (Table 5). In experiment 2 , the amounts $(\mathrm{Mcal} / \mathrm{d})$ of $\mathrm{DE}(P<0.0001)$ and $\mathrm{NE}_{\mathrm{L}}(P<$ 0.0001 ) required for milk production and maintenance were significantly greater for cows consuming diets containing hybrid 3845 corn silage compared with hybrid Quanta corn silage (Table 9). The significant increase in energy required for milk production and maintenance can be attributed to the greater $(P<0.0004)$ milk 
production of cows consuming diets containing hybrid 3845 corn silage (Tables 5 and 9).

The amounts of $\mathrm{DE}$ and $\mathrm{NE}_{\mathrm{L}}$ consumed were subtracted from the $\mathrm{DE}$ and $\mathrm{NE}_{\mathrm{L}}$ required for milk production and maintenance (Table 9). In both experiments, more energy ( $\mathrm{DE}$ and $\mathrm{NE}_{\mathrm{L}}$ ) was consumed than was needed for milk production and maintenance (Table 9). The greater estimation of $\mathrm{DE}$ and $\mathrm{NE}_{\mathrm{L}}$ consumed was partially due to the fact that the energy required for BW change was not estimated and included in the equations for energy required ( $\mathrm{DE}$ and $\mathrm{NE}_{\mathrm{L}}$ ) in these experiments due to experimental design. There was a greater difference between DE intake and DE required $(P<$ $0.005)$ and $\mathrm{NE}_{\mathrm{L}}$ intake and $\mathrm{NE}_{\mathrm{L}}$ required $(P<0.02)$ for cows consuming diets containing hybrid Quanta corn silage compared to hybrid 3845 corn silage in experiment 2 (Table 9). The reason for this is unknown. However, the authors speculate that there was a greater change in BW for cows consuming hybrid Quanta corn silage compared to hybrid 3845 .

\section{CONCLUSIONS}

Mechanical processing affected the nutritive value of corn silage. Total digestible nutrients and $\mathrm{NE}_{\mathrm{L}}$ concentrations $(\mathrm{Mcal} / \mathrm{kg}$ ) of the TMR containing processed corn silage were greater $(P<0.04)$ in experiment 2 and lower $(P<0.02)$ in experiment 1 than for unprocessed corn silage. The increased energy content (TDN and $\mathrm{NE}_{\mathrm{L}}$ concentrations) of the TMR in experiment 2 was related to the greater total tract starch $(P<0.0001)$ and NDF $(P<0.04)$ digestibilities for cows fed processed cornsilage diets. The lower energy content (TDN and $\mathrm{NE}_{\mathrm{L}}$ concentrations) of the TMR in experiment 1 was related to the lower total tract NDF $(P<0.09$; Table 6$)$, ether extract $(P<0.003$; Table 7$)$, and $\mathrm{CP}(P<0.03)$ digestibilities for cows fed processed corn-silage diets. The exact reason for these results in experiment 1 is unknown. However, the authors speculate that it was partially related to the short particle size of the corn silages fed in experiment 1 , which could have increased the rate of passage, and, therefore, decreased the extent of digestibility. This result would especially be true for diets containing processed corn silage because the particle size was slightly shorter than the unprocessed corn silage (experiment 1).

Maturity of corn silage also affected digestibility and energy content of the TMR fed to lactating dairy cows. For hybrid Quanta in experiment 2, the TDN and $\mathrm{NE}_{\mathrm{L}}$ concentrations of TMR containing corn silage harvested at two-thirds ML was greater than at other maturities. This agrees with published data that suggests that the energy value of corn silage tends to be maximized between one-half and two-thirds ML (Harrison et al.,
1996; Bal et al., 1997). However, experiment 1 had some contradictory results. Digestible energy and metabolizable energy, measured via bomb calorimetry, tended to be lower for cows fed TMR containing corn silage harvested at two-thirds ML compared to the less mature silages.

Hybrid of corn silage influenced intake and digestibility of nutrients. The NDF intake was greater for cows consuming diets that contained hybrid 3845 corn silage compared with diets containing hybrid Quanta corn silage. Estimated urinary energy output was lower for diets containing hybrid 3845 corn silage due to the lower concentration of $\mathrm{CP}$ in the diet compared with diets containing hybrid Quanta corn silage. Cows consuming diets that contained hybrid 3845 corn silage had greater $\mathrm{DE}$ and $\mathrm{NE}_{\mathrm{L}}$ requirements for milk production and BW maintenance. This was due to the higher level of milk production for cows consuming diets containing hybrid 3845 corn silage than for those fed hybrid Quanta corn silage diets.

\section{REFERENCES}

Adams, R. S. 1995. Dairy Reference Manual. NRAES-63, 3rd ed. Northeast Regional Agric. Engineering Service. Ithaca, NY.

Association of Official Analytical Chemists. 1990. Official Methods of Analysis. 15th ed. AOAC, Arlington, VA.

Bal, M. A., J. G. Coors, and R. D. Shaver. 1997. Impact of the maturity of corn for use as silage in the diets of dairy cows on intake, digestion, and milk production. J. Dairy Sci. 80:2497-2503.

Bal, M. A., R. D. Shaver, A. G. Jirovec, K. J. Shinners, and J. G. Coors. 2000a. Crop processing and chop length of corn silage: Effects on intake, digestion, and milk production in dairy cows. J. Dairy Sci. 83:1264-1273.

Bal, M. A., R. D. Shaver, K. J. Shinners, J. G. Coors, J. G. Lauer, R. J. Straub, and R. G. Koegel. 2000b. Stage of maturity, processing, and hybrid effects on ruminal in situ disappearance of wholeplant corn silage. Anim. Feed Sci. Technol. 86:83-94.

Buck, G. R., W. G. Merrill, C. E. Coppock, and S. T. Slack. 1969. Effect of recutting and plant maturity on kernel passage and feeding value of corn silage. J. Dairy Sci. 52:1617-1632.

Crocker, L. M., E. J. DePeters, J. G. Fadel, S. E. Essex, H. PerezMonti, and S. J. Taylor. 1998. Ash content of detergent fibers in feeds, digesta, and feces and its relevance in fiber digestibility calculations. J. Dairy Sci. 81:1010-1014.

Dhiman, T. R., M. A. Bal, Z. Wu, V. R. Moreira, R. D. Shaver, L. D. Satter, K. J. Shinners, and R. P. Walgenbach. 2000. Influence of mechanical processing on utilization of corn silage by lactating dairy cows. J. Dairy Sci. 83:2521-2528.

Doggett, C. G. 1998. Evaluation of the effect of corn hybrid and processing on digestion of whole plant silage, grain, and stover. M.S. Thesis, Univ. Idaho, Moscow.

Elliot, J. M., and J. K. Loosli. 1959. Effect of the dietary ratio of hay to concentrate on milk production, ration digestibility, and urinary energy losses. J. Dairy Sci. 42:836-842.

Fassel, V. A. 1978. Quantitative elemental analyses by plasma emission spectrophotometry. Science. 202:183-191.

Fellner, V., M. F. Weiss, A. T. Belo, R. L. Belyea, F. A. Martz, and A. H. Orma. 1988. Urine cup for collection of urine from cows. J. Dairy Sci. 71:2250-2255.

Goering, H. K., R. W. Hemken, N. A. Clark, and J. H. Vandersall. 1969. Intake and digestibility of corn silages of different maturities, varieties, and plant populations. J. Anim. Sci. 29:512-518. 
Goering, H. K., and P. J. Van Soest. 1970. Forage Fiber Analyses (Apparatus, Reagents, Procedures, and Some Applications). Agric. Handbook No. 379. ARS-USDA, Washington, DC.

Harrison, J. H., L. Johnson, R. Riley, S. Xu, K. Loney, C. W. Hunt, and D. Sapienza. 1996. Effect of harvest maturity of whole plant corn silage on milk production and component yield and passage of corn grain and starch into feces. J. Dairy Sci. 79(Suppl. 1):149. (Abstr.).

Harrison, J. H., L. Johnson, C. Hunt, C. D. Doggett, C. A. Rotz, K. Shinners, and D. Sapienza. 1998. Mechanical processing of corn silage: looking back two years. Western Washington Horticultural Assoc. Annu. Convention, Seattle, WA.

Hartnell, G. F., and L. D. Satter. 1979. Extent of particulate marker (Samarium, Lanthanum, and Cerium) movement from one digesta particle to another. J. Anim. Sci. 48:375-380.

Holm, I. B., A. Drews, and N. G. Asp, Lund. 1986. A rapid method for the analysis of starch. Starch/Starke 38:7:224-226.

Huber, J. T., G. C. Graf, and R. W. Engel. 1965. Effect of maturity on nutritive value of corn silage for lactating cows. J. Dairy Sci. 48:1121-1128.

Huber, J. T., J. W. Thomas, and R. S. Emery. 1968. Response of lactating cows fed urea-treated corn silage harvested at varying stages of maturity. J. Dairy Sci. 51:1806-1810.

Johnson, L., J. H. Harrison, D. Davidson, J. Robutti, M. Swift, B. Mahanna, and K. Shinners. 2002. Corn Silage Management I: Effects of hybrid, maturity, and mechanical processing on chemical and physical characteristics. J. Dairy Sci. 85:833-853.

Mertens, D. R., and R. G. Dado. 1993. System of equations for fulfilling net energy and absorbed protein requirements for milk component production. J. Dairy Sci. 76:3464-3478.
Moe, P. W., and H. F. Tyrrell. 1979. Methane production in dairy cows. J. Dairy Sci. 62:1583-1586.

National Research Council. 1989. Nutrient Requirements of Dairy Cattle. 6th rev. ed. Natl. Acad. Sci., Washington, DC.

Philippeau, C., and B. Michalet-Doreau. 1997. Influence of genotype and stage of maturity of maize on rate of ruminal starch degradation. Anim. Feed Sci. Technol. 68:25-35.

Rojas-Bourrillon, A., J. R. Russell, A. Trenkle, and A. D. McGilliard. 1987. Effects of rolling on the composition and utilization by growing steers of whole-plant corn silage. J. Anim. Sci. 64:303311.

$\mathrm{SAS}^{\circledR}$ User's Guide: Statistics, Version 6.03 Edition. 1988. SAS Inst., Inc., Cary, NC.

St. Pierre, N. R., R. Bouchard, G. St. Laurent, G. L. Roy, and C. Vinet. 1987. Performance of lactating dairy cows fed silage from corn of varying maturities. J. Dairy Sci. 70:108-115.

Van Soest, P. J., J. B. Roberston, and B. A. Lewis. 1991. Methods for dietary fiber, neutral detergent fiber, and nonstarch polysaccharides in relation to animal nutrition. J. Dairy Sci. 74:35833597.

Weiss, W. P. and D. J. Wyatt. 2000. Effect of oil content and kernel processing of corn silage on digestibility and milk production by dairy cows. J. Dairy Sci. 83:351-358.

Williams, C. H., D. J. David, and O. Iismaa. 1962. The determination of chromic oxide in fecal samples by atomic absorption spectrophotometry. J. Agric. Sci. (Camb.) 59:381-385.

Young, M. A., T. J. Wistuba, B. E. Brent, L. H. Harbers, and K. K. Bolsen. 1998. The effect of processing corn silage on feedlot performance and nutrient digestibility in growing cattle. J. Anim. Sci. (Suppl. 1):199. (Abstr.). 